\title{
Intertextuality and Biblical Studies: A Review
}

\author{
Dr Steve Moyise \\ (University College)
}

\section{ABSTRACT}

\section{Intertextuality and Biblical Studies: A Review}

The literary term "intertextuality" was introduced into biblical studies in 1989 and concerns the complex relationships that exist between texts. Not surprisingly, this was of interest to those who study the use of the Old Testament in the New, for old texts appear to be given new meaning by being used in new contexts. In this article, I demonstrate the fruitfulness of this approach by offering a survey of five different "types" of intertextuality currently in use today. I conclude that if scholars wish to continue to use the term, they need to clarify which "type" of intertextuality they are using, so that readers can know what is being claimed.

\section{INTRODUCTION}

\subsection{Origins of the term}

Though the study of how texts affect one another is as old as literature itself, Julia Kristeva is generally credited as the first to introduce the term intertextualite into literary discussion in 1969. Drawing on the work of Bakhtin, Kristeva suggests a dialogical relationship between "texts”, broadly understood as a system of codes or signs. Moving away from traditional notions of agency and influence, she suggests that such relationships are more like an "intersection of textual surfaces rather than a point (a fixed meaning)" (1986:36). No text is an island and contrary to structuralist theory, it cannot be understood in isolation. It can only be understood as part of a web or matrix of other texts, themselves only to be understood in the light of other texts. Each new text disturbs the fabric of existing texts as it jostles for a place in the canon of literature. Intertextuality suggests that the meaning of a text is not fixed but open to revision as new texts come along and reposition it (see Moyise 2000).

\subsection{Introduction to biblical studies}

The term was brought to the attention of biblical scholars by two books published in 1989. The first was a collection of essays entitled Intertextuality in Biblical Writings, containing both theoretical discussions and examples of biblical intertextuality. For Vorster (1989:21), intertextuality differs from Redaktionsgeschichte in three significant ways:

First of all it is clear that the phenomenon text has been redefined. It has become a network of references to other texts (intertexts). Secondly it appears that more attention is to be given to text as a process of 
production and not to the sources and their influences. And thirdly it is apparent that the role of the reader is not to be neglected in this approach to the phenomenon of text.

The other book was Echoes of Scripture in the Letters of Paul, by Richard Hays. Hays does not mention Kristeva but draws on Hollander (1981) and Greene (1982) to analyse Paul's subtle use of Scripture, claiming that "the most significant elements of intertextual correspondence between old context and new can be implicit rather than voiced, perceptible only within the silent space framed by the juncture of two texts” (1989:155). It is not surprising that the term has been taken up by those studying the use of the Old Testament in the New, for here we have a great precursor text whose meaning has been significantly altered by the arrival of a new set of texts. Traditional studies have used categories like prophecy and fulfilment, type and anti-type, allegory, targum and midrash to describe this, but intertextuality opens up a new set of possibilities. The examples that follow have been chosen to illustrate five different ways that scholars are using intertextuality today in order to explore the relationship between (what we now call) the Old Testament and the New Testament. I close with some thought on the significance of this new development.

\section{FIVE “TYPES” OF INTERTEXTUALITY}

\subsection{Intertextual echo}

In his ground-breaking book, Richard Hays (1989) speaks of "intertextual echo" in order to suggest that echoes can be quite loud if they reverberate in an echo chamber. Previous studies on the Old Testament in the New have often divided references into quotations, allusions and echoes. There are no agreed definitions, but generally a quotation involves a self-conscious break from the author's style to introduce words from another context. There is

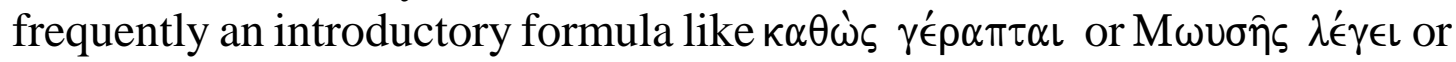
some grammatical clue such as the use of $\dot{\delta} \tau$. An allusion is usually woven into the text rather than "quoted", and is often rather less precise in terms of wording. Naturally, there is considerable debate as to how much verbal agreement is necessary to establish the presence of an allusion. An echo is a faint trace of a text and might be quite unconscious, emerging from minds soaked in the scriptural heritage of Israel.

It is not difficult to see why studies have often focused on quotations. There is not usually much controversy as to the source text and the author is clearly "intending" the reader to acknowledge the citation by drawing attention to it. However, if a subtext is well known, the slightest of allusions is sometimes sufficient to evoke its presence. A popular game show on television required contestants to guess the title of a piece of a music from its opening bars. Sometimes, the winner managed this from just two notes. 
Similarly, not many words are necessary to evoke Israel's Passover or Exile. The themes are so well known (and repeated liturgically) that a seemingly innocuous mention of "doorposts" (in the appropriate language, of course) might well be sufficient. As Hays says of Paul's letters, (1989:155).

Echoes linger in the air and lure the reader of Paul's letters back into the symbolic world of Scripture. Paul's allusions gesture toward precursors whose words are already heavy with tacit implication.

\subsubsection{Philippians 1:19 and the book of Job}

Hays (1989:22).illustrates his approach with a reading of Philippians 1:19 ("for I know that through your prayers and the help of the Spirit of Jesus Christ this will result in my deliverance"). The last part of this verse is in

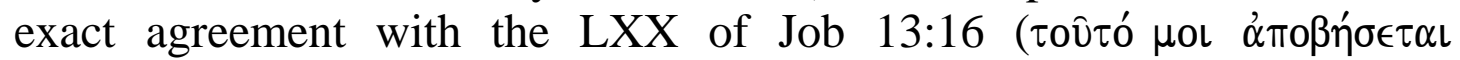
eis $\sigma \omega \tau \eta \rho i \alpha \nu)$. Hays notes that the echo is not marked and Paul's words are quite understandable without recourse to Job. But the echo does add something to a reading of the text, for it invites the reader to see parallels between the two situations. He says:

"By echoing Job's words, Paul the prisoner tacitly assumes the role of righteous sufferer, as paradigmatically figured by Job... thereby he implicitly transfers to himself some of the significations that traditionally cluster about the figure of Job"

Intertextual echo is not typology or midrash. Paul is not suggesting that his suffering is in any sense a "fulfilment" of the Job passage. Rather, the echo sets up a link which invites traffic, both similarities and differences. In terms of similarities, Hays notes that Job's pain is compounded by the pious advice of his own friends, just as Paul's imprisonment is compounded by those who preach Christ out of envy (Phlp 1:15-17). As Hays (1989:23) says,

"the echo whispers a suggestion that the rival preachers have assumed the mantle of Job's hollow comforters; the falsehood of both will be exposed ultimately in the judgment of God".

On the other hand, Paul is able to rejoice in his sufferings in a way that Job could not, because he is clear that God is on his side. Paul possesses what Job lacked, namely, the security of knowing that his suffering is in the 
service of Christ. Thus:

"whereas Job, seeing through a glass darkly, endured his suffering with obdurate puzzlement, Paul, suffering as an apostle of Christ, interprets his suffering as a participation in the sufferings of the crucified Christ and thus finds himself able to rejoice in the midst of adversity” (1989:22).

\subsection{Narrative intertextuality}

In her monograph, Paul and his Story. (Re)Interpreting the Exodus Tradition (1999), Sylvia Keesmaat shows how the story or framework of the Exodus tradition has influenced Paul's exegesis in Galatians and Romans 8. She claims that intertextuality is the most fruitful way of describing this, for the presence of the Exodus story in Paul's writings is not limited to his verbatim quotations, but is activated by all sorts of allusions and echoes. Keesmaat notes that Paul is unlike the authors of Jubilees, the Qumran commentaries and the Targums, for he is not concerned to offer an explicit retelling of the biblical story or a systematic exegesis of a given text. Paul relies on the familiarity of the Exodus story to frame his particular arguments. The issue is not so much whether Paul invites his readers to remember a particular text but to remember a particular story (1999:228):

The intertextual matrix upon which Paul draws is not just a cluster of motifs and themes which jostled around with one another in the collective mind of first-century Judaism. This matrix is actually a larger story, told and retold in past remembrance and future hope to shape Israel's identity and future expectation.

\subsubsection{Romans 8:18-39 and the Exodus story}

Keesmaat (1999) argues that what has often been seen as ad hoc allusions in Romans 8:18-39, are in fact a careful retelling of the Exodus story. The key themes of the passage are adoption, being led by the Spirit, crying out to God as father, suffering, gaining an inheritance and entering into glory. These have often been understood as benefits for the individual Christian, but when it is recognised that these are all key themes in the Exodus story, the perspective changes. The besetting sin of the wilderness generation was their desire to return to Egypt and slavery again. The spirit-inspired Christian must not follow their example, but enter into the promised inheritance. It is the story which is governing the shape of Paul's use of the Old Testament (see 1 
Cor 10; 2 Cor 3 for more explicit examples). Thus the Gentile Christians in Rome are exhorted not to abandon the tradition

"for their own experience of God in Christ Jesus is rooted in the whole story of Israel. Adam and Abraham explain their past, the exodus gives meaning to their present, the whole story provides hope for their future"(1999:228).

Narrative intertextuality shows the importance of stories shaping the way we think and the way we express ourselves.

\subsubsection{Continuity and discontinuity}

Narrative intertextuality not only involves continuity but also some measure of discontinuity, for the ancient story is both "disrupted" and "regenerated" when used in new and perhaps unforeseen situations. Against those who argue that Paul used scripture in an ad hoc way, Keesmaat emphasises continuity. The allusions and echoes in Romans 8:18-39 are not chosen at random, but evoke the story of the exodus as a powerful meta-narrative for Paul's argument. However, she also recognizes:

(a) that the Exodus story which Paul tells is one that has already been transformed by prophets such as Hosea, Isaiah and Jeremiah, and traditions such as Wisdom, Sirach, Baruch and Enoch;

(b) "the invasive action of God in Jesus Christ introduced a new element into the story, an unexpected twist in the plot";

(c) all retelling of the past, as opposed to merely repeating it, involves an element of transformation (1999:233). Narrative intertextuality then emphasises both the continuing role of a significant story, while also acknowledging that each new retelling is in some sense a reshaping of that story.

\subsection{Exegetical intertextuality}

In his monograph, From a broken covenant to circumcision of the heart: Pauline intertextual exegesis in Romans 2:17-29, Timothy Berkley (2000) thinks the key to understanding Paul's argument is his exegesis of particular passages of scripture. These are not explicitly quoted, but lie beneath the surface. Berkley acknowledges the work of Hays and others on the importance of intertextual echo, but wishes to focus his study on those passages which betray detailed exegetical activity. This activity is not 
necessarily shown in the text, but must be assumed in order to make sense of Paul's argument.

\subsubsection{Romans 2:17-29}

The first part of Berkley's book is concerned with developing criteria to establish the texts on which Paul has done detailed exegesis. He thinks these are Genesis 17, Deuteronomy 28-30, Jeremiah 7 and 9, and Ezekiel 36. Interestingly, he places very little importance on the explicit quotation of Isaiah 52:5 in Romans 2:24, arguing that explicit quotations are often simply crowning proof-texts, rather than sites of exegetical activity. As for Paul's strategy in Romans 2:17-29, Berkley (2000:155) says that Paul must show that Jews cannot rely on their status as God's people to save them from wrath:

Paul must address Jewish possession of the law and circumcision, supposed to be identifiers of the Jews as a people enjoying the benefits of a special status before God. By undercutting Jewish reliance on the covenant of the law (2:17-24), questioning the value of circumcision when the law is broken (2:25-27), and specifying meaningful circumcision as circumcision of the heart (2:28-29), Paul in effect redefines the meaning of "Jew" to be a spiritual, rather than simply an ethical or national, definition.

Though not evident on the surface of the text, Berkeley suggests that catchword links led Paul from Genesis 17 to Deuteronomy 28-30, where circumcision is defined as "heart circumcision" and God's concern is for that which is hidden rather than that which is visible. It also took him to Ezekiel 36:26 (which he had already used in 2 Cor 3:3) to show that the bodily sign was to be replaced by a new heart and a new spirit. This is the positive side of Paul's argument. The negative side is provided by Jeremiah 7:4-9 and 9:22-25. In Jeremiah 7, the Israelites are warned that they cannot trust in the temple if they "steal, murder, commit adultery, swear falsely, make offerings to Baal, and go after other gods” (Jr 7:9). In Romans 2:21-22, Paul asks his readers whether they preach against stealing, adultery and idolatry but continue to do those same things themselves. Jeremiah 9 warns against boasting in anything except the Lord. Romans 2:17 indicts those who rely on the law and boast in their relationship with God. Furthermore, Jeremiah 9 closes with the judgement that "the house of Israel is uncircumcised in heart" (Jr 9:26).

Thus Berkley’s understanding of the passage is that circumcision has 
become uncircumcision because Israel has failed to keep the law. But circumcision of the flesh had already been reinterpreted by Deuteronomy, Jeremiah and Ezekiel to mean circumcision of the heart, that is, something which is inward and spiritual, and this is now possible through faith in Christ. It is only by tracing the "intertextual exegesis" that lies behind Romans 2:17-29 that we are able to understand Paul's argument. Indeed, Berkley (2000:151) goes as far as saying:

Paul would probably have a difficult time supporting, or even coming to, such a view without the underlying exegesis of these OT texts. Their use, however, enables Paul to reach this conclusion in a way that is exegetically, if not theologically, legitimate in his contemporary context.

This does, of course, raise the question that if the "intertextual exegesis" were so necessary for the validity of Paul's argument, why did he not include it in the text? Could he assume that his readers would have guessed what Berkley now claims to have discovered? And if not, does that mean that Paul's rhetoric was essentially unpersuasive?

\subsection{Dialogical intertextuality}

Narrative intertextuality emphasises continuity, though it acknowledges that each retelling of a story is in some sense a reshaping of that story. "Dialogical intertextuality" makes the claim that the source text is not always as malleable as traditional categories like allegory, typology and midrash suggest. Sometimes the source text is so powerful that it brings with it associations and connotations that are not easily silenced. As Davidson (1985:117) says of T S Eliot's, The Waste Land, “The work alluded to reflects upon the present context even as the present context absorbs and changes the allusion" (1985:117). An author does not "master" a text in the sense of "controlling" its meaning. The text fights back, so to speak, reminding the reader that it once belonged elsewhere and has certain "rights". I call this "dialogical intertextuality" for it suggests that the influence between texts is two-way: the new affects the old while the old affects the new. I illustrate this from my own monograph of 1995, The Old Testament in the Book of Revelation.

\subsubsection{The lion and the lamb of Revelation 5}

In the vision of Revelation 5, John is told that "the Lion of the tribe of Judah, 
the root of David, has conquered" but when he looks, he sees "a Lamb standing as if it had been slaughtered" (Rv 5:4-5). This juxtaposition is seen by many scholars as the key to the interpretation of the book. Caird (1984:75), for example, says:

"Wherever the Old Testament says 'Lion', read 'Lamb'”. Wherever the Old Testament speaks of the victory of the Messiah or the overthrow of the enemies of God, we are to remember that the gospel recognizes no other way of achieving these ends than the way of the Cross.

John Sweet agrees, claiming that the "Lion of Judah, the traditional messianic expectation, is reinterpreted by the slain Lamb: God's power and victory lie in self-sacrifice” (1990:125). However, I argue that the powerful image of the lion is not so easily silenced. Indeed, as John's story continues, it would seem that the lamb has picked up many of the warrior traits of the lion. For example, in the very next chapter, the people of the world are said to hide from the "wrath of the lamb" (Rv 6:16). His enemies receive double for their sins and "will be tormented with fire and sulphur in the presence of the holy angels and in the presence of the Lamb" (Rv 14:10). There is a battle in Revelation 17 but the outcome is not in doubt, for the "Lamb will conquer them, for he is Lord of lords and King of kings" (Rv 17:14). As Resseguie (1998:129) says, "the Lamb, though not in nature a strong animal, is a being of incontrovertible might in this book".

"Dialogical intertextuality" aims to describe a dynamic rather than a static state of affairs. John's use of the lion/lamb juxtaposition is not resolved simply by declaring that the lamb reinterprets the lion, for one must also give an account of how the lion has affected the lamb. As Greene says of certain Renaissance poetry, "The text makes a kind of implicit criticism of its subtexts, its authenticating models, but it also leaves itself open to criticism from [the text]... it had begun by invoking” (1982:45). In my interpretation of Revelation 5, John has left us with a tension that is not easily resolved. As Decock says, "inter-textuality opens up a space to see the continuing cooperation of these surrounding texts in the production of meaning" (1999:404).

\subsection{Postmodern intertextuality}

In the 1989 book, Intertextuality in Biblical writings, Ellen van Wolde describes the way a text is produced and read: 
The writer assigns meaning to [their] own context and in interaction with other texts... shapes and forms [a] text. The reader, in much the same way, assigns meaning to the generated text in interaction with other texts [they] know... A writer does not weave a web of meanings that the reader merely has to follow, but... presents them to the reader as a text. The reader reacts to the offer and enters into a dialogue with the possibilities the text has to offer (1989:47).

On this understanding, reading always has a subjective element for "all interpretations must necessarily delimit a text's possible references in order to come up with a coherent meaning” (Beal 1992:30-1). And this involves choice and hence vested interests, for every "text - as an intersection of other textual surfaces - suggests an indeterminate surplus of meaningful possibilities. Interpretation is always a production of meaning from that surplus” (Beal 1992:31).

Vernon Robbins (1996) notes that most examples of biblical intertextuality have already made fundamental decisions, such as (1) giving priority to Jewish texts rather than Greek or Roman texts; (2) emphasising the influence of texts over other expressions of culture; and (3) confining itself to historical and literary modes of discourse. Thus "the ideological nature of all interpretation manifests itself in the interplay between the choice of a mode of interpretive discourse and the choice of dimensions of the text the interpreter reinscribes" (1996:213). In showing how complex it is to pindown "influence", "postmodern intertextuality" draws attention to the fact that choices have already been made. As Robbins (1996:101) says:

Different ideologies... establish different boundaries for intertextual analysis and these different boundaries encourage significantly different strategies of interpretation... [S]ocio-rhetorical criticism uses a strategy of reading and rereading a text from different angles to produce a 'revalued' or 'revisited' rhetorical interpretation... The goal is to use the resources of other disciplines 'on their own terms' and to allow these resources to deconstruct and reconfigure the results of a particular focus and set of strategies in a particular discipline.

\subsubsection{The woman at the well (John 4)}

According to Schneiders (1991), the "traditional" reading of John 4 sees Jesus (the male) in conversation with the Samaritan (the female) but operating on a different (higher) plane. Her mind is set on earthly matters. She has come to the well for ordinary water (4:7). When Jesus speaks of 
"living water", all she can think of is "Sir, you have no bucket". When he explains that, "Everyone who drinks of this water will be thirsty again, but those who drink of the water that I will give them will never be thirsty", her interest is aroused but only to save herself the daily journey (4:15). When Jesus exposes the fact that she has had five husbands, she tries to embroil him in a theological discussion about places of worship. But once again, Jesus is on a higher plane. Worship is not about place, but spirit and truth (4:24). Lastly, she voices a basic tenet of her Samaritan beliefs, "I know that Messiah is coming... When he comes, he will proclaim all things to us" (4.25). Jesus replies, "I am he, the one who is speaking to you" (4.26). Schneiders (1991:194) says this typical male reading of the story,

presents the woman as a disreputable (if interesting) miscreant who, failing in her attempt to distract Jesus from her sexually disgraceful past, surrenders to his overpowering preternatural knowledge of her, alerts her fellow townspeople to his presence, and then fades from the scene as they discover him for themselves and come to believe in him.

However, a different reading is possible, for it is Jesus who asks for a (literal) drink. It is not that the woman can only think in earthly terms; this is what Jesus asks for. He is sitting by Jacob's great well and asks her for a (material) drink. But the woman looks beyond the material to ask why social taboos are being ignored for "Jews do not share things in common with Samaritans" (4:9). Jesus replies that he can offer "living water", which the woman (rightly) takes as a religious claim to be superior to Jacob and the patriarchs. Jesus then elaborates that the water he offers is such that those who drink of it will never again be thirsty, for it "will become in them a spring of water gushing up to eternal life". The woman is interested and replies using the same metaphor as Jesus used: "Sir, give me this water, so that I may never be thirsty or have to keep coming here to draw water" (4:15). Thus it is possible to read the text as a serious theological exchange and not a (foolish) woman continually misunderstanding the (superior) male. On this reading, she is far more astute than Nicodemus in the previous episode (3:1-21), and the disciples in this one (4:27).

However, it is problematic to this reading that Jesus says in 4:18: "You are right in saying, 'I have no husband'; for you have had five husbands, and the one you have now is not your husband. What you have said is true!” Is this not confirmation that the story is about her "sexually disgraceful past", even if male scholars have exaggerated this? But it has often been noted that (1) adultery is a common metaphor in the Old Testament for spiritual unfaithfulness, which is precisely what the Jews thought of the Samaritans; 
and (2) that the reference to five husbands is an allusion to the re-population of Samaria in 2 Kings 17:24,29.

The king of Assyria brought people from Babylon, Cuthah, Avva, Hamath, and Sepharvaim, and placed them in the cities of Samaria in place of the people of Israel; they took possession of Samaria, and settled in its cities... every nation still made gods of its own and put them in the shrines of the high places that the people of Samaria had made, every nation in the cities in which they lived.

This allegorical interpretation was once quite popular, though the Enlightenment has made it difficult for moderns to accept it (allegory was the enemy of rationalism). However, given the symbolic nature of much of John's Gospel, one has to admit that it is a possibility. If the reader was supposed to recognise that "Destroy this temple, and in three days I will raise it up" (Jn 2:19) was a reference to the "temple of his body", it would certainly be possible that a chapter which discusses whether Jerusalem or Gerizim is the proper place for worship, assumes the reader is acquainted with Samaritan history. That being so, Stephen Moore (1994) notes that there is more at stake here than simply deciding between competing interpretations. Those who wish to condemn the woman for taking everything literally (the typical "male" interpretation) can do so only by insisting that 4:18 ("five husbands") must be literal rather than figurative. In other words (Moore 1994:49):

They can condemn her only if they participate in her error, can ascribe a history of immorality to her only by reading as "carnally" as she does - at which point the literal reading of 4:18 threatens to become a displaced reenactment of yet another Johannine episode, one in which an unnamed woman is similarly charged with sexual immorality by accusers who themselves stand accused (8:1-11).

"Postmodern intertextuality" draws attention to the fact that there is always more than one way of configuring (interpreting) a text which inevitably belongs to a web of other texts. It is thus less concerned with determining the meaning of a text as describing the complex interactions that make such a single meaning impossible. 


\section{CONCLUSION}

\subsection{The fruitfulness of intertextuality}

From the studies presented above, it should be clear that intertextuality has proved to be a fruitful and creative concept. Breaking away from traditional descriptions of prophecy and fulfilment, typology, allegory and midrash, it invites readers to focus on complexity rather than assume that we have understood a text because we have called it something (like midrash). Intertextual studies suggest that under the right conditions, allusions and echoes might be just as important as explicit quotations for an understanding of a text. Some will worry that this introduces a more speculative area of study than explicit quotations, since allusions and echoes are naturally more elusive than quotations. But I suggest that this cannot be avoided. As I have said elsewhere, one would not expect a music critic to confine his or her comments to the loudest instruments of an orchestra. It is often the fine nuances that define a particular good performance (Moyise 1995:18).

\subsection{The drawbacks of intertextuality}

It will also be clear from the studies presented above that scholars use the term "intertextuality" in very different and, in some cases, incompatible ways. In particular, some use it to gather evidence to support a particular interpretation (notably Berkley), while others use it to show the inevitable tensions and complexity involved in the use of the Old Testament in the New (e.g. Moyise). Greater clarity would be achieved if scholars made clear what type of intertextuality they were using (as I have sought to do here), or specified the particular theorist on which they depend (e.g. Kristeva, Barthes, Derrida, Eco, Riffaterre). Aichele and Phillips (1995:11) would like to confine the use of the term to its postmodern roots and regard the more "conservative" uses as "thin":

Traditional "banal" source critical ("intertextual") explanations of citation, allusion, allegoresis and the like, which claim a concern for history, prove exceedingly thin by comparison because they fail to take into account the historical and cultural nature of textual productivity and the implicature of readers and readings in the production of meaning... what they are really concerned with is agency and influence.

On the other hand, the word "intertextuality" has taken on a life of its own, and now has to be interpreted (or abandoned) in the light of current practice rather than the originating moment (an irony not lost on Aichele and Phillips). My suggestion is that, in the light of current usage, it is best used as 
an "umbrella" term for the complex interactions that exist between "texts" (in the broadest sense). It is an evocative word, like "textuality", which reminds us that such interactions are rarely straightforward. However, the weakness of this suggestion is obvious; no one can tell what is being claimed when different scholars speak of intertextuality. It is hoped that the taxonomy of five "types" of intertextuality presented in this article will go some way to meeting this need.

\section{Consulted Literature}

Aichele, G \& Phillips, G A 1995. Introduction: Exegesis, Eisegesis, Intergesis, Semeia 69-70, 7-18.

Beal, T K 1992. Ideology and intertextuality: Surplus of meaning and controlling the means of production, in: D N Fewell, (ed), Reading between texts: Intertextuality and the Hebrew Bible, Louisville: Westminster John Knox, 27-39.

Berkley, T W 2000. From a broken covenant to circumcision of the heart: Pauline intertextual exegesis in Romans 2:17-29, (SBL Dissertation Series 175). Atlanta: SBL

Caird, G B 1984. The Revelation of St John the divine. ( $2^{\text {nd }}$ Ed). London: A \& C Black.

Davidson, H 1985. T. S. Eliot and hermeneutics: Absence and interpretation in the Waste Land. Baton Rouge: Louisiana State University Press.

Decock, P B 1999. The scriptures in the book of Revelation, Neotestamentica 33, 373410.

Draisma, S (ed) 1989. Intertextuality in Biblical writings. Kampen: Kok.

Fewell, D N (ed). Reading between texts:Intertextuality and the Hebrew Bible, Louisville: Westminster John Knox.

Greene, T M 1982. The light in Troy: Imitation and discovery in Renaissance poetry. New Haven: Yale University Press.

Hays, R B 1989. Echoes of scripture in the letters of Paul. New Haven: Yale University Press.

Hollander, J 1981. The figure of echo: A mode of allusion in Milton and after. Berkeley: University of California Press.

Keesmaat, S C 1999. Paul and his Story: (Re)Interpreting the Exodus Tradition (JSNTSup 181). Sheffield: Sheffield Academic Press

Kristeva, J 1986 [1969]. Word, dialogue and novel, in: T Moi (ed), The Kristeva Reader. New York: Columbia University Press, 34-61.

Moi, T (ed) 1986. The Kristeva Reader. New York: Columbia University Press. 
Moore, S D 1994. Poststructuralism and the New Testament: Derrida and Foucault at the foot of the cross. Minneapolis: Fortress Press.

Moyise, S 1995. The Old Testament in the Book of Revelation (JSNTSup 115). Sheffield: Sheffield Academic Press

-, 2000. Intertextuality and the study of the Old Testament in the New Testament, in: S Moyise, (ed), The Old Testament in the New Testament (JSNTSup189). Sheffield: Sheffield Academic Press, 14-41.

Resseguie, J L 1998. Revelation Unsealed: A Narrative Critical Approach to John's Apocalypse. Leiden: Brill.

Robbins, V 1996. The tapestry of early Christian discourse: Rhetoric, society and ideology. London: Routledge.

Schneiders, S 1991. The revelatory text: Interpreting the New Testament as sacred scripture. San Fransisco: Harper San Fransisco.

Sweet, J 1990. Revelation (TPI NT Commentaries, $2^{\text {nd }}$ ed). London: SCM

Van Wolde, E 1989. Trendy Intertextuality, in: S Draisma (ed), Intertextuality in Biblical Writings, Kampen: Kok, 43-9.

Vorster, W 1989. Intertextuality and Redaktionsgeschichte, in: S Draisma, S (ed), Intertextuality in Biblical Writings, Kampen: Kok, 15-26. 